\title{
A comparative study of the prevalence of asymptomatic bacteriurea (ASB) among elderly diabetics and non diabetics with their antibiotic resistant pattern
}

\author{
Shadma Yaqoob ${ }^{1}$, Vaibhav Shukla ${ }^{2}$, Mastan Singh ${ }^{3}$, Priyanka Shukla ${ }^{4, *}$, Fareya Haider ${ }^{5}$ \\ ${ }^{1,4}$ Associate Professor, ${ }^{2}$ Professor, ${ }^{3}$ Professor and HOD, ${ }^{5}$ Assistant Professor, Dept. of Microbiology, ERA's Lucknow Medical \\ College, ERA University, Lucknow, Uttar Pradesh, India \\ *Corresponding Author: \\ Email: drpriyanka.microbio@gmail.com
}

Received: $23^{\text {rd }}$ April, 2018

Accepted: $30^{\text {th }}$ May, 2018

\begin{abstract}
Introduction: Asymptomatic bacteriuria is the most common problem in elderly diabetics may be due to high glucose concentration in the urine of such patients that favour the growth of uropathogens.

Objective: This study was done to determine the prevalence of asymptomatic bacteriuria in diabetic and non diabetic patients, to determine the uropathogens responsible for ASB and also to know the antimicrobial susceptibility pattern of the pathogens.

Materials and Methods: Urine samples were collected from elderly diabetics and non diabetics. Cultures Antibiotic susceptibility tests were performed using standard microbiological technique.

Results: ASB was found to be $9.8 \%$ and $4.6 \%$ in diabetics and non diabetics Escherichia coli were the most common isolates followed by Klebsiella pneumonia, Imipenem, Nitrofurantoin were the most sensitive antibiotics against the urinary isolates.

Conclusion: The patients may progress to symptomatic UTI so treatment is advisable in elderly cases of asymptomatic bacteriuria with poorly controlled diabetes but after culture and sensitivity.
\end{abstract}

Keywords: Asymptomatic bacteriurea bacteriuria, Diabetics and non diabetics, Culture, Antibiotic susceptibility.

\section{Introduction}

Asymptomatic bacteriuria is the most common problem in developingcountries. It is defined as the presence of quantitative count of bacteria $\left(10^{5}\right.$ colonyforming units (CFU) per ml)in clean-voided midstream urine sample of an individual withoutsymptoms or signs of urinary tract infection (UTI) like burning sensation during micturation, dysuria, increased frequency of micturation, urgency, lower abdominal pain, fever etc. ${ }^{1,2}$ Urine is normally sterile but in favourable condition it can be good growth medium for bacteria.In diabetic patients high glucose concentration in the urine favours the growth of uropathogens causing Asymptomatic bacteriuria. ${ }^{3,4}$ Asymptomatic bacteriuria in diabetic patients is higher compared to non-diabetics that was proved by many studies. ${ }^{5}$ Baldwin AD did his study on autopsy in 1940 and showed that $18 \%$ of the cases withdiabetes had a urinary tract infection (UTI). ${ }^{6}$ The patients may progress to symptomatic UTI so treatment is advisable in elderly patients of asymptomatic bacteriuria with uncontrolled and long duration diabetes.

\section{Materials and Methods}

A comparative Study was conducted in the Department of Microbiology, in Tertiary care Hospital Lucknow. Diabetic and non diabetic patients with age 50 or more having no urinary complaints were enrolled for this study after obtaining informed consent. Clean voided mid-stream urine sample from 264 patients (132 diabetics and 132 non diabetics) attending OPD between 9 a.m. to 12 p.m. on Friday, for routine check up were collected. After collection samples were sent for screening tests, culture and sensitivity. Two methods were used for screening tests, ie, Gram's staining of uncentrifuged urine and wet mount for pus cell counts. After screening culture was done on MacConkey agar and blood agar using standard loop. The plates were read after $24 \mathrm{~h}$ of aerobic incubation at $37^{\circ} \mathrm{C}$. Sample was considered positiveif the growth having single organism obtained in counts $>10^{5}$ colonyforming units $(\mathrm{cfu} / \mathrm{mL})$. The standardized Kirby-Bauer disc diffusion method was used for antibiotic susceptibility testing according to the Clinical and Laboratory Standards Institute guidelines. The antibiotics tested were: Amoxyclav, Ceftriaxone/Ceftazidine, Nitrofurantoin, Norfloxacin, Doxycycline, Imipenem, Erythromycin/Clindamycin, Vancomycin, Teicoplanin for Gram negative and Gram positive bacteria.

\section{Result}

Total 264 urine samples were processed, 132 of diabetics and 132 non diabetics. Out of 132 samples of elderly diabetics $13(9.8 \%)$ were found to be culturepositive and $6(4.6 \%)$ were culture positive out of 132 samples of elderly non diabetics. Escherichia coli was the most significant bacteria in the study, 7 (53.8\%) in diabetics and $4(66 \%)$ in non diabetics. Other isolates were Staphylococcus aureus, Enterococcus, Proteus, Klebsiella, Coagulase negative staphylococcus, Pseudomonas. Antibiotic-susceptibility tests was done and the most effectiveantibiotics for the urinary isolates were found to be Imepenem and Nitrofurantoin. Isolates 
showed high resistance to Amoxyclav, Ceftriaxone, Doxycycline, Norfloxacin. Pseudomonas isolated from the urine sample of a patient, age 72 with poorly controlled sugar level, was multidrug resistant. It was also observed that the mean $\mathrm{HbAlc}$ levels were significantly higher in the patients with asymptomatic bacteriuria. In non diabetics Ceftriaxone and Norfloxacin were moderately sensitive.

Table 1: Resistant pattern of bacterial isolates in elderly diabetics (n=132)

\begin{tabular}{|l|c|c|c|c|c|c|c|c|c|c|}
\hline Isolates & A/C & CEF/CEFTA & NITRO & NOR & DOXY & ERY/CLIN & VAN & TEICO & IMEP \\
\hline E coli & $\mathrm{R}$ & $\mathrm{R}$ & $\mathrm{S}$ & $\mathrm{R}$ & $\mathrm{S}$ & & & & $\mathrm{S}$ \\
\hline Ecoli & $\mathrm{R}$ & $\mathrm{R}$ & $\mathrm{S}$ & $\mathrm{R}$ & $\mathrm{S}$ & & & & $\mathrm{S}$ \\
\hline Ecoli & $\mathrm{R}$ & $\mathrm{S}$ & $\mathrm{S}$ & $\mathrm{R}$ & $\mathrm{S}$ & & & & $\mathrm{S}$ \\
\hline Ecoli & $\mathrm{R}$ & $\mathrm{S}$ & $\mathrm{S}$ & $\mathrm{S}$ & $\mathrm{S}$ & & & & $\mathrm{S}$ \\
\hline Ecoli & $\mathrm{S}$ & $\mathrm{S}$ & $\mathrm{R}$ & $\mathrm{S}$ & $\mathrm{R}$ & & & & $\mathrm{S}$ \\
\hline Ecoli & $\mathrm{R}$ & $\mathrm{R}$ & $\mathrm{R}$ & $\mathrm{R}$ & $\mathrm{S}$ & & & & $\mathrm{S}$ \\
\hline KLEB & $\mathrm{R}$ & $\mathrm{R}$ & $\mathrm{S}$ & $\mathrm{R}$ & $\mathrm{S}$ & & & & $\mathrm{S}$ \\
\hline KLEB & $\mathrm{R}$ & $\mathrm{R}$ & $\mathrm{S}$ & $\mathrm{R}$ & $\mathrm{R}$ & & & & $\mathrm{S}$ \\
\hline STAPH & $\mathrm{R}$ & & $\mathrm{S}$ & $\mathrm{S}$ & $\mathrm{R}$ & $\mathrm{R}$ & $\mathrm{S}$ & $\mathrm{S}$ & \\
\hline CONS & $\mathrm{R}$ & & $\mathrm{S}$ & $\mathrm{R}$ & $\mathrm{R}$ & $\mathrm{R}$ & $\mathrm{S}$ & $\mathrm{S}$ & \\
\hline PSEUD & $\mathrm{R}$ & $\mathrm{R}$ & $\mathrm{R}$ & $\mathrm{R}$ & & & & & $\mathrm{R}$ \\
\hline E coli & $\mathrm{R}$ & $\mathrm{S}$ & $\mathrm{S}$ & $\mathrm{R}$ & $\mathrm{R}$ & & & & $\mathrm{S}$ \\
\hline PSEUD & $\mathrm{R}$ & $\mathrm{S}$ & $\mathrm{R}$ & $\mathrm{R}$ & $\mathrm{R}$ & & & & $\mathrm{S}$ \\
\hline
\end{tabular}

E.coli-Escherichia coli, Kleb-klbsiella, Staph-Staphylococcus aureus, CONS-Coagulase negative staphylococcus, Pseud- seudomonas

A/C-Amoxyclav, CEF/CEFTA-ceftriaxone/ceftazidine, NITRO-Nitrofurantoin, NOR-norfloxacin, DOXYdoxycyclin, ERY/CLIN-Erythromycin/Clindamycin, VAN: Vancomycin, TEICO: Teicoplanin, IMP-Imipenem. *for pseudomonas

Table 2. Resistant Pattern of Bacterial Isolates in Elderly nondiabetics ( $=132$ )

\begin{tabular}{|l|c|c|c|c|c|c|c|c|c|}
\hline S. No. & A/C & CEF & NITRO & NOR & DOXY & CLINDA & VAN & TEICO & IMEP \\
\hline E coli & R & R & S & R & S & & & & S \\
\hline Ecoli & S & R & S & R & S & & & & S \\
\hline Ecoli & R & S & S & S & R & & & & S \\
\hline Ecoli & R & S & S & S & S & & & & S \\
\hline KLEB & R & R & R & S & R & & & & S \\
\hline CONS & S & S & S & R & S & R & S & S & S \\
\hline
\end{tabular}

\section{Discussion}

ASB is most common among diabetics as compared to non diabetics that was clearly demonstrated in this study. The prevalence of ASB among elderly diabeticswas $9.8 \%$ and $4.6 \%$ in non diabetics. This result was very similar with the study done by BK Jha et al $(9.43 \%), 18.4 \%$ in study done by Manish Rijal et al and $10.3 \%$ by A. Adhikari et al. ${ }^{7-9}$ Butin some study prevalence of ASB in diabetic patients was comparatively higher. ${ }^{10,11}$ The most common microorganisms in this study was Escherichia coli, $53.8 \%$ in diabetics $66 \%$ in non diabetics followed by Klebsiella, pseudomonas, staphylococcus, coagulase negative staphylococcus. This result was supported by various other studies and E.coli was the predominant pathogen in diabetic $(62.7 \%)$ and in non-diabetic patients $(54.1 \%)$ followed by klebsiella in a study done by P. Sathishkumar et $\mathrm{al}^{12}$ and similar results with Escherichia coli $(47.7 \%)$ followed by Klebsiella was shown by Manish Rijaletal ${ }^{9}$ also. Among 11 Gram negative bacteria only 1 was resistant to Imipenem that was pseudomonas isolated from the urine sample of diabetic patients, age 72 with the mean HbA1c levels significantly higher and was multidrug resitant. Nitrofurantoin was the sensitive antibiotics after the Imepenem, against the urinary isolates similar pattern was also reported in a study of Manish Rijal et al. ${ }^{9}$ Most isolated microorganisms were resistant to Amoxyclav and Norfloxacin. Gram positive bacteria were sensitive to Vancomycin and Teicoplanin. The use of these drugs to treat bacteriuria in diabetic patients should be with caution. Strict and regular follow up is needed.

\section{Conclusion}

This study showed that ASB was most common problems among diabetic patients. The prevalence of asymptomatic bacteriurea among diabetics and non diabetics were $9.8 \%$ and $4.6 \%$. So routine screening tests and urine culture is recommended to diagnose asymptomatic bacteriurea among diabetics especially in elderly patients with uncontrolled sugar level in order to avoid the complications. Gram negative organisms 
were most commonly isolated especially E. coli. The most effective antibiotic against Gram negative isolates were Imipenem and Nitrofurantoin Vancomycin and Teicoplanin were effective for gram positive isolates. The patients may progress to symptomatic UTI so treatment is advisable in elderly cases of asymptomatic bacteriuria having uncontrolled and long duration diabetes. But antibiotic should be advised only after culture and sensitivity has been performed. This would prevent emerging drug resistance amongst bacteria.

Acknowledgements: We thank the staff for their assistance to carry out this study.

\section{References}

1. Trautner Barbara W, Gupta Kalpana (2008) Urinary Tract Infections.

2. Pyelonephritis, and Prostatitis In: chapter 288: Harrisons Principles of Internal Medicine p.18.

3. Jicolle LE, Bradley S, Colgan R, Rice JC, Schaeffer A, Hooton TM. Infectious diseases society of America guidelines for the diagnosis and treatment of asymptomatic bacteriuria in adults. Clin Infect Dis. 2005;40(5):643-54.

4. Joshi N, Caputogm, Weitekampmr, Karchmer AW Infections in patients with diabetes mellitus. Nengl J Med. 1999;341(25):1906-12.

5. Hari A, Sinha A (2013) Asymptomatic bacteriuria in patients with diabetes attending a tertiary care level-a descriptive study. Int J Prev Therapeu Med. 2013;1:23479205.
6. Nicolle LE (2003) Asymptomatic bacteriuria: when to screen and when to treat. Infect Dis Clin North Am. 2003;17:367-394.

7. Baldwin $\mathrm{AD}$, Root HF. Infections of the upper urinary tract in the diabetic patient. $N$ Engl J Med. 1940;244-250.

8. Jha BK, Singh YI, Khanal LK, Yadab VC, Sanjana RK. (2009) Prevalence of asymptomatic bacteriuria among elderly diabetic patients residing in Chitwan. Kathmandu Univ Med J (KUMJ). 2009;7:157-161.

9. Adhikaree A. Asymptomatic bacteriurea in diabetics adults. J Lumbini Med Coll. 2015;3(2),25-9.

10. Manish Rijal M, Neupane B, Bhandari P, Aryal S (2015) Asymptomatic Bacteriuria in Elderly Patients with Diabetes Attending a Tertiary Care Center. J Trop Dis. 3:162. doi:10.4172/2329891X.1000162 vol 3 issue 3

11. Hari A, Sinha A (2013) Asymptomatic bacteriuria in patients with diabetes attending a tertiary care level-a descriptive study. Int J Prev Therapeu Med. 2013;1:23479205.

12. Singh L, Murthy R, Singh H, Nigam P. Asymptomaticbacteriurea in patients with type-2 diabetes mellitus. NJIRM. 2013;(6):1-4.4.

13. Sathish Kumar. Sch J App Med Sci. 2016;4(10A):35903592.

How to cite this article: Shadma Y, Shukla V, Singh M, Shukla P, Haider F. A comparative study of the prevalence of asymptomatic bacteriurea (ASB) among elderly diabetics and non diabetics with their antibiotic resistant pattern. Indian $\mathbf{J}$ Microbiol Res. 2018;5(3):339-341. 